\title{
Gene expression in the brain-pituitary adipose tissue axis and luteinising hormone secretion during pubertal development in the gilt
}

\author{
C. R. Barb', G.J. Hausman' and R. Rekaya² \\ 'Animal Physiology Research Unit, USDAARS, Richard B. Russell Agriculture Research Center, PO Box \\ 5677, Athens, GA 30604, USA; and 'Animal and Dairy Science Department, University of Georgia, \\ Athens, GA 30602, USA
}

The occurrence of puberty in the female is due to the interplay of central and peripheral mechanisms in which the hypothalamic-pituitary-ovarian axis regulates growth and gonadal function, as well as adipocyte hormone secretion. Hypothalamic GnRH mRNA expression increased at 3.5 months of age and declined by 6 months of age. Concomitant with the age related reduction in the oestrogen negative feedback on $\mathrm{LH}$ secretion was a decline in hypothalamic oestrogen receptor- $\alpha(E R \alpha)$ expression and increased expression of repressor of ER activity gene (REA) at 210 days of age. Hypothalamic proopiomelanocortin expression increased at 6 months of age followed by increased expression of progesterone receptor (PR) membrane compliment-1 and steroid membrane binding protein gene at 210 days of age. This represents development of the endogenous opioid peptide-progesterone dependent LH inhibitory pathway. Adipose tissue leptin and insulin like growth factor -I (IGF-I) gene expression increased with age and adiposity. Pituitary transcription factors, steroidogenic factor 1 (SF 1 ) and $\mathrm{Lh} \times 3$, and $\mathrm{LH} \beta$ and $F S H \beta$ gene expression increased with age. These resuits identify key hypothalamic and pituitary genes associated with changes in LH secretion and growth during pubertal development and adipose tissue genes and secreted proteins related to maturation of the neuroendocrine axis and puberty.

\section{Introduction}

The occurrence of puberty in the female is the manifestation of the interplay between central and peripheral mechanisms in which the hypothalamic-pituitary-ovarian axis regulates growth and gonadal function, as well as adipocyte hormone secretion. The integral components of this axis are functional before the normal onset of puberty (Kraeling and Barb, 1990). Little is known, however, about the mechanisms within the brain which bring these various components into the proper temporal relationship to initiate puberty. Induction of oestrus and ovulation in prepubertal gilts with hourly i.v. injections of $\mathrm{GnRH}$ demonstrated the importance of pulsatile GnRH secretion (Lutz et al., 1985). The gonadostat hypothesis is one of the most widely accepted theories regarding neuroendocrine mechanisms controlling onset of puberty 
and contends that as an animal ages, sensitivity to oestrogen negative feedback on pulsatile LH secretion declines (Ramirez and McCann, 1963). The pig appears to conform to the gonadostat hypothesis because onset of puberty is immediately preceded by a significant increase in pulsatile $\mathrm{LH}$ secretion in the face of increasing oestrogen secretion (Lutz et al., 1984; Barb et al., 2000). In addition, the neuroendocrine axis became less sensitive to the suppressive effects of exogenous oestrogen on $\mathrm{LH}$ secretion as gilts progressed from the prepubertal to peripubertal state (Barb et al., 2000). This change in sensitivity could be the result of brain maturational processes which reflect decreased inhibitory inputs and (or) increased stimulatory inputs to $\mathrm{GnRH}$ neurons. Lastly, there is a positive genetic correlation between backfat thickness and average daily gain with first detectable oestrus and first breeding in the gilt (Mabry et al., 1985; Tummaruk et al., 2000). Thus, adipose derived factors may play a role in the timing of puberty. The purpose of this review is: first, to identify hypothalamic and pituitary genes associated with changes in LH secretion and growth during pubertal development and second, to examine adipose tissue gene expression related to maturation of the neuroendocrine axis and puberty.

\section{GnRH/ LH pulse generator}

In general, in the gilt, mean serum LH concentration and serum LH pulse frequency increased from 15 days of age to maximum levels between 110 and 125 days of age, then decreased until 150 days of age and remained suppressed (juvenile nadir) until the peripubertal period (Pelletier et al., 1981; Diekman et al., 1983; Lutz et al., 1984; Camous et al., 1985; Kraeling and Barb, 1990). Further, a reduction in the negative feedback effect of oestrogen on LH secretion occurred during the peripubertal period in the gilt. There is little information regarding mechanisms within the brain that brings the various components of the reproductive axis together in a proper temporal relationship to initiate puberty (Esbenshade et al., 1982; Prunier et al., 1993; Clapper et al., 1993a; Clapper et al., 1993b). Hypothalamic GnRH mRNA expression increased markedly by 3.5 months of age compared to 7 day-old pigs and declined by 6 months of age (Lin et al., 2001; Table 1). This expression pattern is consistent with the LH secretory pattern during development; particularly around the time of the juvenile nadir. However, in a subsequent study hypothalamic GnRH mRNA expression remained unchanged between 150 and 210 days of age in the prepubertal gilt (C. R. Barb, unpublished). Similarly, in the intact female primate, hypothalamic GnRH content did not vary during the juvenile to pubertal transition (Ma et al., 1994). Furthermore, in the intact male monkey, $\mathrm{GnRH}$ gene expression was similar among juvenile and adult animals (Vician et al., 1991). In the female rat, hypothalamic GnRH mRNA expression increased gradually during development between day 10 and 41 (Gore et al., 1996) and increased significantly on the day of vaginal opening. This occurred after establishment of a diurnal pattern of LH secretion (Ojeda and Urbanski, 1994b), suggesting that level of hypothalamic GnRH gene expression may not be a necessary antecedent for puberty.

Excitatory and inhibitory inputs. Glutamatergic N-methyl-D-aspartate (NMDA) receptor activation accelerated puberty (Brann and Mahesh, 1997) and NMDA receptor blockade delayed puberty in the rat (Ojeda and Terasawa, 2002). In juvenile male monkeys, NMDA receptor activation initiated a pubertal pattern of $\mathrm{LH}$ secretion (Gay and Plant, 1988). In agreement with the studies above, stimulation of NMDA receptor enhanced circulating concentrations of $\mathrm{LH}$ in the prepubertal gilt (Estienne et al., 1995). Furthermore, administration of GnRH antiserum abolished the ability of NMDA to increase LH secretion (Sesti and Britt, 1992). This is consistent with the idea that activation of the glutamatergic system stimulates $\mathrm{GnRH}$ release in the prepubertal gilt. Several studies have proposed that the pubertal increase in GnRH secretion may result from a reduction in inhibitory input as well as an increased flow of excitatory input (Ojeda and Urbanski, 1994; Terasawa and Fernandez, 2001; Plant and Barker-Gibb, 2004). 
Table 1. Hypothalamic expression of OB-rb, preproorexin, corticotropin releasing factor (CRF), somatostatin (SS), gonadotropin releasing hormone $(\mathrm{GnRH})$ and proopiomelanocortin (POMC) mRNA, and adipose tissue expression of leptin (LS mean \pm SE) for 106 day-old foetuses $(n-3)$ and 3.5 month-old $(n-3)$ and 6 month-old $(n-2)$ gilts."

\begin{tabular}{lllclrr}
\hline Item & 106 day-old foetus & 7 day-old pig & 3.5 month-old pig & 6 month-old pig & P-Value \\
\hline OB-rb & $0.15 \pm 0.05^{d}$ & $0.19 \pm 0.05^{d}$ & $0.44 \pm 0.06^{\mathrm{c}}$ & $0.38 \pm 0.06^{\mathrm{e}}$ & $<0.05$ \\
Preproorexin & $0.70 \pm 0.06^{\mathrm{d}}$ & $0.59 \pm 0.06^{\mathrm{d}}$ & $0.96 \pm 0.06^{\mathrm{c}}$ & $0.75 \pm 0.07^{\mathrm{d}}$ & $<0.05$ \\
CRF & $0.81 \pm 0.17^{\mathrm{d}}$ & $0.44 \pm 0.27^{\mathrm{d}}$ & $0.10 \pm 0.17^{\mathrm{d}}$ & $0.78 \pm 0.21^{\mathrm{d}}$ & $\mathrm{NS}^{\mathrm{b}}$ \\
SS & $0.52 \pm 0.11^{\mathrm{d}}$ & $0.62 \pm 0.11^{\mathrm{d}}$ & $1.32 \pm 0.13^{\mathrm{c}}$ & $0.36 \pm 0.13^{\mathrm{d}}$ & $<0.02$ \\
GnRH & $0.21 \pm 0.03^{\mathrm{d}}$ & $0.19 \pm 0.03^{\mathrm{d}}$ & $0.74 \pm 0.04^{\mathrm{a}}$ & $0.38 \pm 0.04^{\mathrm{d}}$ & $<0.02$ \\
POMC & $0.31 \pm 0.05^{\mathrm{d}}$ & $0.30 \pm 0.05^{\mathrm{d}}$ & $0.26 \pm 0.05^{\mathrm{d}}$ & $0.73 \pm 0.06^{\mathrm{c}}$ & $<0.01$ \\
\hline
\end{tabular}

\footnotetext{
- Expressed as a ratio of OB-rb, neuropeptide of leptin mRNA relative to $18 \mathrm{~s}$ rRNA.

b NS: Non significant.

c ND: Not determined.

d.e. Means in a row with different superscripts differ; $P$, level of significance.

From Lin et al., 2001.
}

The gamma-aminobutyric acid (GABA) neuronal pathway represents a major inhibitory neurotransmitter system that contributes to the inhibitory input to $\mathrm{GnRH}$ neurons (Ojeda and Urbanski, 1994; Terasawa and Fernandez, 2001). The pubertal increase in $\mathrm{GnRH}$ secretion may result from a reduction in GABAergic inhibition and a concomitant increase in glutamatergic excitatory input (Terasawa and Fernandez, 2001). Other neurosecretory pathways may provide inhibitory and excitatory input to the GnRH system during pubertal development such as NPY and EOP and norepinephrine (for a review, see Kraeling and Barb, 1990; Terasawa and Fernandez, 2001; Ojeda and Terasawa, 2002). Therefore, regulation of hypothalamic GnRH expression may not play a critical role in onset of puberty, but the summation of increased excitatory and decreased inhibitory input on $\mathrm{GnRH}$ neurons may be the determining factor.

\section{Steroid and age dependent changes}

\section{Oestrogen}

To determine if there is an age and steroid dependent change in adipose leptin expression associated with $\mathrm{LH}$ secretion, ovariectomised (OVX) prepubertal gilts at 90,150 and 210 days of age were implanted with oestrogen and blood and adipose tissue samples were collected 7 days post-implant. Oestrogen-induced leptin mRNA expression in adipose tissue occurred in the 210 day-old animals (time of expected puberty) but not in younger animals (Qian et al., 1999). This was associated with a reduction in the negative feedback regulation of pulsatile L.H secretion (Barb et al., 2000; Fig. 1) and an age dependent increase in hypothalamic long form leptin receptor (OB-rb) expression (Lin et al., 2001; Table 1) and serum leptin concentrations (Qian et al., 1999). These events coincided with increased hypothalamic expression of repressor of oestrogen receptor activity (REA) between 150 to 210 days of age in the pig (C. R. Barb, unpublished; Table 2). This gene was reported to suppress oestrogen receptor (ER) transcriptional activity (Montano et al., 1999). Thus, REA may play an important role in determining sensitivity of oestrogen target neurons during pubertal development.

Maturational change in sensitivity to oestrogen may reflect decreased GnRH neuronal ER concentration, a reduction in inhibitory inputs and (or) an increase in stimulatory inputs to the $\mathrm{GnRH}$ neuron (Ojeda and Terasawa, 2002; Sisk and Foster, 2004) and (or) a decline in ER concentrations in an intermediary neuronal pathway that regulates $\mathrm{GnRH}$ secretion (Dierschke et al., 1974; Day et al., 1984). To that extent, Day et al. (1984) observed in the heifer that the number of ER in the anterior hypothalamus and medial basal hypothalamus declined in associa- 

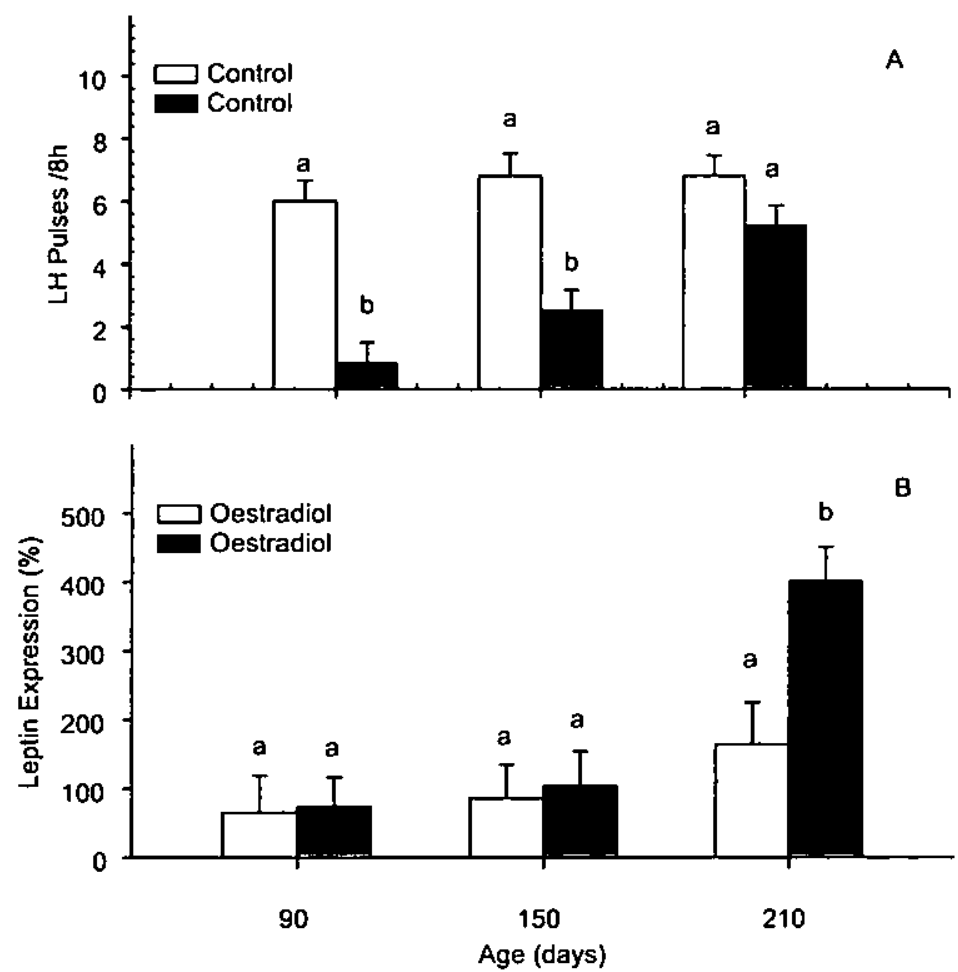

Fig. 1 (A) Luteinising hormone pulse frequency (mean \pm SE) for 90, 150 and 210 day-old gilts implanted with osmotic pumps containing oestradiol or vehicle control $(n=6$ per treatment/ age, except 150 day-old control, $n=5$ ). Bars with different superscripts differ $(P<0.05)$. (B) Leptin mRNA expression for 90,150 and 210 day-old pigs implanted with osmotic pumps containing oestradiol or vehicle control. Quantification of leptin mRNA expression by laser densitometry was expressed as a percentage of leptin mRNA relative to $28 \mathrm{~S}$ ribosomal RNA and normalized for an mRNA pool run on each gel. Means with different superscripts differ ( $P<0.01$ ). Modified from Qian et al. 1999 and Barb et al., 2000).

Table 2. Microarray analysis of age related changes in hypothalarnic gene expression from 90 to 150 ( $n-5)$, 150 to $210(n-5)$ and 90 to $210(n-5)$ days of age in the prepubertal gilt.

\begin{tabular}{|c|c|c|c|c|}
\hline Gene Description & $\begin{array}{l}90 \text { to } 150 \\
\text { days old }\end{array}$ & $\begin{array}{l}150 \text { to } 210 \\
\text { days old }\end{array}$ & $\begin{array}{l}90 \text { to } 210 \\
\text { days old }\end{array}$ & $P$ value \\
\hline $\begin{array}{l}\text { Steroid Related } \\
\text { Progesterone receptor } \\
\text { Membrane comp. } 1\end{array}$ & $\mathrm{Nc}$ & $U p$ & Up & $2.8 \times 10^{-5}$ \\
\hline $\begin{array}{l}\text { Steroid membrane BP } \\
\text { Repressor estrogen }\end{array}$ & Nc & $\mathrm{Up}^{*}$ & $U p^{* *}$ & ${ }^{*} 2.8 \times 10^{.5} ; * * 0.006$ \\
\hline receptor activity & $\mathrm{Nc}$ & $U_{p}^{*}$ & Up** & ${ }^{*} 0.0002 ;{ }^{* *} 0.002$ \\
\hline $\begin{array}{l}\text { Oestrogen receptor } \alpha \\
\text { Oestrogen receptor } \beta \\
\text { Appetite Related }\end{array}$ & $\begin{array}{l}\mathrm{Nc} \\
\mathrm{Nc}\end{array}$ & $\begin{array}{l}\text { Down } \\
\text { Nc }\end{array}$ & $\begin{array}{l}\mathrm{Nc} \\
\mathrm{Nc}\end{array}$ & 0.002 \\
\hline $\begin{array}{l}\text { MC3-R } \\
\text { MCH precursor } \\
\text { GH Related }\end{array}$ & $\begin{array}{l}\text { Nc } \\
\text { Down }\end{array}$ & $\begin{array}{l}\text { Up* } \\
\text { Up }\end{array}$ & $\begin{array}{l}\text { Up** } \\
\mathrm{Nc}\end{array}$ & $\begin{array}{c}{ }^{*} 0.0003 ; * * 0.002 \\
2.8 \times 10^{-5}\end{array}$ \\
\hline Somatostatin & $\mathrm{Nc}$ & Up & Nc & 0.0002 \\
\hline
\end{tabular}

MC3R: Melanocortin-3 receptor; $\mathrm{MCH}$ precursor: Melanin-concentrating hormone precursor;

MC4R: Melanocortin- 4 receptor: Nc: No change. ${ }^{*} P$ value for 150 to 210 day-old gilts: ${ }^{* *} P$ value for 90 to 210 day-old gilts. 
tion with increased $\mathrm{LH}$ secretion and onset of puberty. In the prepubertal pig, concentrations of hypothalamic nuclear ERß were not different at $\mathbf{4}$ and 5.5 months of age (Diekman and Anderson, 1983). We observed no change in hypothalamic ERß expression between 150 and 210 days of age, but $E R \alpha$ declined during this time (C. R. Barb, unpublished; Table 2). Thus, it is reasonable to question whether or not a developmental change in hypothalamic $E R \alpha$ mRNA expression represents a change in sensitivity to steroid negative feedback. Alternatively, the type of ER expressed may be of greater importance. Work in the rat demonstrated that $85 \%$ of the GnRH neurons contained ERß (Hrabovszky et al., 2001). In the female mouse, both ER $\alpha$ and ERß are involved in oestrogen negative feedback of LH secretion in vivo. However, only $E R \alpha$ appears to be critical for oestrogen-negative feedback suppression of GnRH mRNA expression (Dorling et al., 2003). Whether or not the pubertal decrease in sensitivity to oestrogen negative feedback is a result of related changes in $\mathrm{GnRH}$ neuronal steroid hormone receptor expression remains unclear. It is possible that changes in the gonadostat may be mediated by developmental upstream changes in neuronal regulatory control of $\mathrm{GnRH}$ secretion. $\mathrm{GnRH}$ neuronal activity is regulated by multiple synaptic inputs (Ojeda and Urbanski, 1994) that are subject to regulation by ovarian steroids (Herbison, 1998). Moreover, Herbison (1998) suggested that two potentially independent oestrogen-sensitive neuronal systems exist, an inhibitory and stimulatory pathway for $\mathrm{GnRH}$ secretion.

\section{Progesterone}

We have previously reported that EOP modulation of $\mathrm{LH}$ secretion is progesterone dependent in the mature gilt (Barb et al., 1985; Barb et al., 1986; Barb et al., 1988). Furthermore, EOP act at the hypothalamus to modulate GnRH release (Barb et al., 1994). Evidence in the gilt suggests that puberty is initiated in part by a decrease in intrinsic central nervous system (CNS) inhibitory input and/or a reduction in the sensitivity to the negative feedback action of ovarian steroids (Kraeling and Barb, 1990; Kraeling et al., 1992). We suggest that the EOP-progesterone dependent pathway that inhibits $\mathrm{LH}$ secretion is the result of a maturational process (Barb et al., 1988). In this regard direct synaptic contacts between proopiomelanocortin (POMC) and $\mathrm{GnRH}$ containing neurons were found in the arcuate nucleus of the hypothalamus in the rat (Thind and Goldsmith, 1988; Chen et al., 1989). In the pig, POMC containing neurons are located in the area within the hypothalamus that is involved in GnRH secretion (Kineman et al., 1988; Kineman et al., 1989). Moreover, hypothalamic POMC expression increased by 6 months of age, a time when GnRH gene expression was suppressed in the prepubertal gilt (Lin et al., 2001; Table 1). These events preceded increased hypothalamic expression of progesterone receptor (PR) membrane compliment- 1 and steroid membrane binding protein gene at 210 days of age (C. R. Barb, unpublished; Table 2). Taken together the above data represent maturational changes in key components of the EOP-progesterone dependent pathway that inhibits $\mathrm{LH}$ secretion in the mature gilt.

\section{Pituitary}

The anterior pituitary gland integrates signals of hypothalamic and peripheral origin. Hormones secreted from the anterior pituitary gland regulate growth, reproduction and energy homeostasis among other physiological functions. There are a number of regulatory proteins, steroid hormone receptors and transcription factors that play a role in anterior pituitary development (Savage et al., 2003). Regulation of $\mathrm{LH} \beta$ and FSHB subunits is a critical rate limiting step in the production of biologically active LH and FSH. Thus, factors that control synthesis of these glycoprotein hormone subunits are necessary for reproductive function (Savage et al., 2003). 
Two candidate genes known to play a critical role in pituitary development and production of hormones, which are necessary for growth and reproduction in rodents and humans, have been identified in the pig. Steroidogenic factor 1 (SF1) and Lhx3 LIM homeodomain transcription factor genes were recently mapped to an area on chromosome 1 , which is associated with a QTL for growth and puberty (Smith et al., 2001). The Lhx3 is required for anterior/intermediate pituitary development and differentiation of $\mathrm{GH}, \mathrm{PRL}, \mathrm{TSH}, \mathrm{LH}, \mathrm{FSH}$ cells while SF 1 , a nuclear receptor, is required for gonadotrope development (Savage et al., 2003). The absence of these genes resulted in loss of $\mathrm{GH}, \mathrm{LH}, \mathrm{PRL}, \mathrm{FSH}$ and TSH secretion, gonadal agenesis, reduced growth and failure to reach puberty (Netchine et al., 2000). In the pig, a transient increase in Lhx3 gene expression occurred during the time of pituitary organogenesis, and pituitary cell differentiation with a high level of expression in the mature pituitary gland (Smith et al., 2001). Consistent with these developmental changes in Lhx3 and SF 1 expression, we recently observed an increase in pituitary $\mathrm{LH} \beta$ and FSH 3 gene expression by 150 days of age in the gilt. Thus, identification of other pituitary regulatory genes that are developmentally regulated may provide potential candidate genes for genetic analysis of growth and reproductive traits.

\section{Oestrogen receptor}

The biological action of oestrogen on the anterior pituitary gland is manifested through the ER. Like many other reproductive tissues, the pituitary gland expresses two isoforms, ER- $\alpha$ and- $\beta$. We observed no change in pituitary ERß and PR expression during development in gilts, but ER $\alpha$ expression increased by 210 days of age compared to 150 days of age (C. R. Barb, unpublished; Table 2). Similarly, pituitary concentrations of cytoplasmic or nuclear ERß and progesterone receptor (PR) were similar among 1, 2.5, 4 or 5.5 month-old gilts (Diekman and Anderson, 1982). In general, the biological role of $E R \alpha$ is to regulate PRL and gonadotrope gene expression and lactotrope cell growth, where as ERß stimulates PR expression and is involved in GnRH self-priming in the gonadotrope (Savage et al., 2003). A recent report by SanchezCriado et al. (2004) utilizing selective receptor agonists for $E R \alpha$ and $-\beta$ demonstrated that $E R \alpha$ mediated oestrogen stimulation of PRL secretion and basal and $\mathrm{GnRH}$-induced $\mathrm{LH}$ and FSH secretion, whereas oestrogen increased the number of pituitary cells expressing PR via the ERß in the rat. Thus, the ER appears to play a critical role in development of the pituitary's capability to secret $\mathrm{LH}$ and $\mathrm{FSH}$.

\section{Growth and metabolic signals}

In addition to developmentally related maturation of the neuroendocrine axis, permissive peripheral signals associated with attainment of a minimum percentage of body fat (Frisch 1984), which are of adipocyte origin, such as leptin or IGF-I (Barb et al., 1998a; Barb et al., 2002) may play a role in the timing of puberty. During the prepubertal period, expression of a number of hypothalamic genes associated with appetite and growth regulation appear to be developmentally regulated (Table 1 and 2). For example hypothalamic OB-rb mRNA expression, adipose tissue leptin expression and serum leptin concentrations increased by 3.5 months of age (Qian et al., 1998; Lin et al., 2001). In addition, hypothalamic melanocortin 3 receptor (MC3-R), and melanin-concentrating hormone $(\mathrm{MCH})$ precursor expression were up-regulated between 150 and 210 days of age (C. R. Barb, unpublished; Table 2). These genes and their encoded proteins are well positioned anatomically to interact with GnRH (Kraeling and Barb, 1990) and GHRH (Leshin et al., 1994) neurons and appetite regulating neurons (Lawrence et al., 1999; Matteri 2001). Consistent with this idea, central administration of leptin increased $\mathrm{GH}$ secretion and suppressed feed intake in the gilt (Barb et al., 1998b). Furthermore, leptin 
stimulated GnRH release from porcine hypothalamic explants (Barb et al., 2004). These changes in the growth/reproductive axis appear to be in concert with the timing of puberty.

The early growth pattern of the gilt is almost linear. Growth sharply increased from the postnatal period (Robison 1976). However, serum GH concentrations and pituitary response to GHRH declined with age in the pig (Dubreuil et al., 1987). Greater hypothalamic somatostatin mRNA expression at 3.5 months (Lin et al., 2001) and 210 days of age (C. R. Barb, unpublished) compared to 6 month and 150 days of age, respectively, support the idea of an age related decline in $\mathrm{GH}$ secretion due to increased somatostatin secretion. Furthermore, Drisko et al. (1998) reported a temporal relationship between hypophysial-portal blood concentration of somatostatin and generation of serum GH pulses in the pig.

In the pig, the pubertal rise in circulating IGF-I concentration (Lee et al., 1991) occurred concomitantly with increased IGF-I expression in adipose tissue (G. J. Hausman, unpublished; Table 3), decreased pituitary response to GHRH (Dubreuil et al., 1987) and increased LH secretion (Lutz et al., 1984; Fig. 2). These observations are consistent with the idea that IGF-I may modulate hypothalamic release of $\mathrm{GnRH}$ and factors regulating $\mathrm{GH}$ secretion. Spencer et al. (1991) reported that ICV administration of IGF-I suppressed $\mathrm{GH}$ secretion in the foetal pig. Although the central effect of IGF-I on GH secretion was lost during maturation in the pig (Barb et al., 2002), pituitary sensitivity to IGF-I modulation of the $\mathrm{GH}$ response to GHRH from porcine pituitary cells in culture was dependent on age of the pituitary donor (Barb et al., 2002). Furthermore, IGF-I-induced LH secretion was greater in porcine pituitary cells from follicular phase gilts compared to luteal phase and OVX gilts (Whitley et al., 1995). Thus, during pubertal development, endogenous IGF-I may contribute to the regulation of $\mathrm{LH}$ and $\mathrm{GH}$ secretion from the anterior pituitary, and therefore, the timing of puberty in the pig.

Table 3. Microarray analysis of age related changes from 90 to 150 (n -5$), 150$ to 210 (n -5 ) and 90 to 210 (n - 5) days of age in adipose tissue gene expression in the inner subcutaneous layer of the prepubertal gilt.

\begin{tabular}{lcccc}
\hline Gene description & $\begin{array}{c}90 \text { to } 150 \\
\text { days old }\end{array}$ & $\begin{array}{c}150 \text { to } 210 \\
\text { days old }\end{array}$ & $\begin{array}{c}90 \text { to } 210 \\
\text { days old }\end{array}$ & P value \\
\hline Leptin & $\mathrm{Up}$ & $\mathrm{Nc}$ & $\mathrm{Up}$ & $2.8 \times 10^{-5}$ \\
IGF-2 & $\mathrm{Nc}$ & $\mathrm{Nc}$ & $\mathrm{Up}$ & 0.001 \\
IGF-1 & $\mathrm{Nc}$ & $\mathrm{Up}$ & $\mathrm{Up}$ & 0.005 \\
INSL.3 & $\mathrm{Nc}$ & $\mathrm{Up}$ & $\mathrm{Up}$ & 0.005 \\
IFNy,lL-1 $\alpha$ & $\mathrm{Nc}$ & $\mathrm{Nc}$ & 0.003 \\
\hline
\end{tabular}

IGF: Insulin-like growth factor; INSL-3: Insulin-like growth factor-3; IL-1 $\alpha$ : Interleukin-1 $\alpha$; INF- $\gamma$. Interferon- $\gamma$; Nc: No change.

\section{Adipose tissue, an endocrine organ}

In addition to maturational changes at the CNS, the onset of puberty may be linked to attainment of a critical body weight or a minimum percentage of body fat (Frisch, 1984). Metabolic mass and food intake and subsequent metabolic rate may play a permissive role in the timing of puberty (Frisch, 1984; Barb and Kraeling, 2004). Moreover, initiation of puberty may also be influenced by metabolic factors of peripheral origin. It was postulated that metabolic signals are important in initiation of puberty in the pig and primate by Cameron et al. (1985) and Barb et al. (1997), respectively. Identification of such signals has remained elusive, primarily because there is a large number of peripherally originating substances that can act centrally to modify neuronal activity. Recent studies demonstrated that adipose tissue plays a dynamic role in modulating physiological mechanisms and whole-body homeostasis (Ahima and Flier, 2000). Adipose tissue constitutes the largest amount of stored energy in the body (Loftus, 1999). Energy homeostasis depends on a balance among several factors, such as feeding behaviour, adi- 

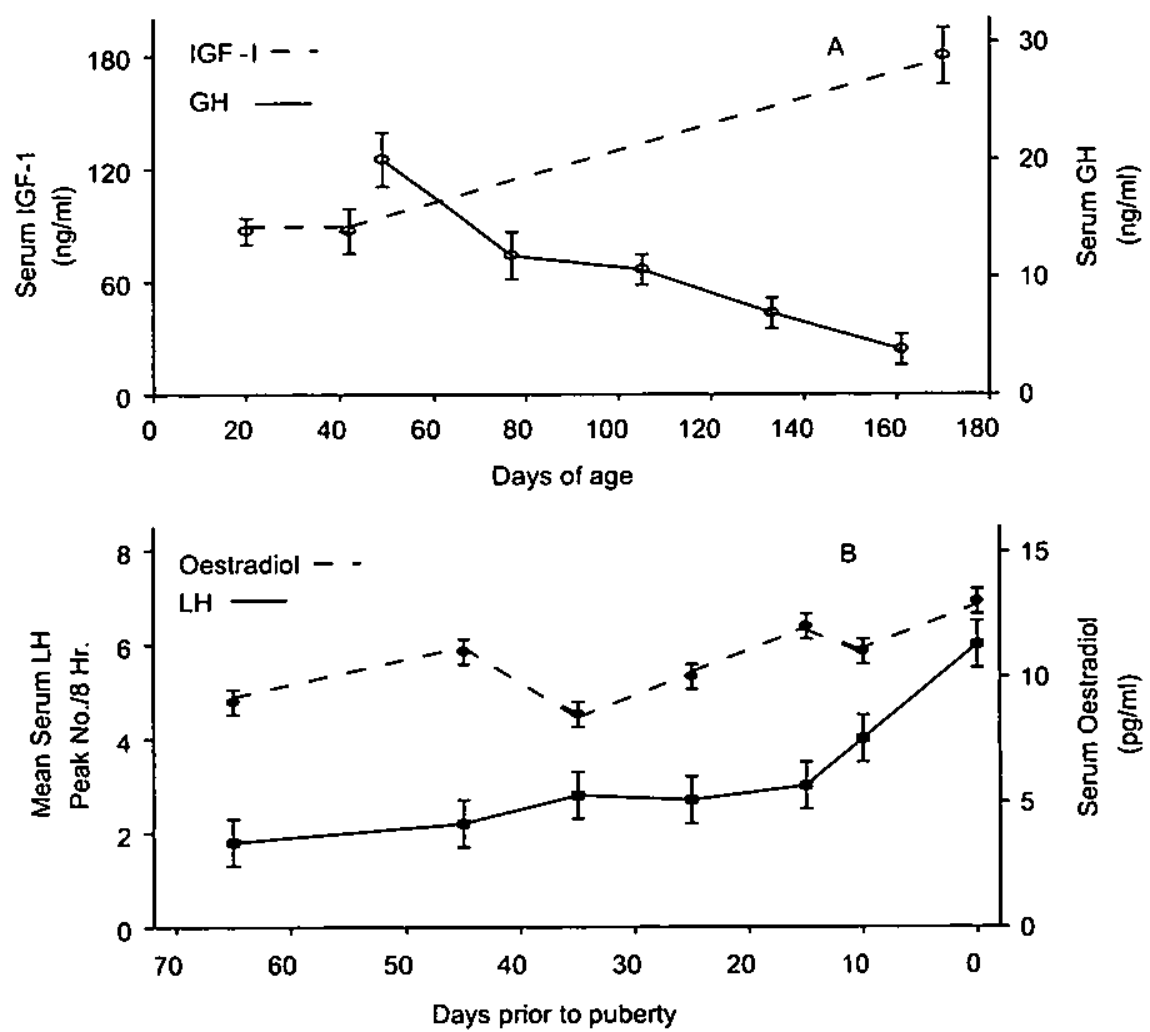

Fig. 2 (A) Serum IGF-I and GH concentrations at 20,40,60,80, 100, 120, 140 and 160 days of age. (B) Serum oestradiol and $\mathrm{LH}$ concentrations at day 65, 45, 35, 25, 15 and10 before oestrus and the day of oestrus. Modified from Lee et al., 1991; Dubreuil et al., 1987; Lutz et al., 1984.

pose tissue mass and activation of catabolic processes, such as reproduction. Alterations in serum concentrations of many hormones and growth factors that regulate adipocyte function and leptin secretion are associated with developmental changes in body weight, nutritional status or adipose tissue mass (Barb et al., 2001). Microarray analysis revealed that 21 secreted protein genes were expressed 40 fold in neonatal porcine adipose tissue and porcine preadipocyte cultures, such as agouti-related protein (AGRP), growth differentiation factor-9ß (GDF- 9ß), and tumour growth factor- $\alpha$ (TCF $\alpha$; G.J. Hausman, unpublished). Moreover, RT-PCR analysis identified the agouti gene in pig adipose tissue. Proteomic analysis of conditioned media from adipose tissue and preadipocyte cultures identified several secreted proteins, such as relaxin, interleukin-8 (IL-8) and insulin like growth factor binding protein (IGFBP-5; G. J. Hausman, unpublished). Furthermore, there was an age related change in gene expression in the inner subcutaneous adipose tissue layer (G. J. Hausman, unpublished). Leptin expression increased between 150 and 210 days of age when compared to 90 day-old gilts. In addition, IGF-I and insulin-like factor-3 (INSL-3) gene expression increased between 150 and 210 days of age (G. J. Hausman unpublished; Table 3). These studies demonstrate expression of several major secreted proteins in pig adipose tissue, which may act as autocrine /paracrine factors to regulate adipocyte activity and centrally to influence the neuroendocrine axis. As cited above, hypothalamic OB-rb mRNA expression increased by 3.5 months of age and remained elevated at 6 months of age (Lin et al., 2000) and the fact that leptin stimulated $\mathrm{LH}$ secretion from pig pituitary cells and $\mathrm{GnRH}$ release from hypothalamic tissue in vitro (Barb et al., 2004) suggests that leptin acts through the hypothalamic-pituitary axis. Thus, 
these reports support the idea that adipose tissue functions as an endocrine organ and may play a role in establishing onset of puberty.

\section{Conclusion}

Evidence has been presented that suggests puberty, and its associated increase in LH pulse frequency in the pig, is brought about by an integration of adipose tissue derived metabolic signals along with maturational changes in the hypothalamic-pituitary axis. The proposed sequence of developmental events involves increased excitatory and reduced inhibitory input on GnRH neurons. A concomitant age related reduction in oestrogen negative feedback on $\mathrm{LH}$ secretion and an associated increase in hypothalamic ER $\alpha$ and REA expression, an age related increase in anterior pituitary LHß and FSHß gene expression, and increased expression of adipose derived metabolic signals, such as leptin and IGF-I play a role in establishing onset of puberty (Fig. 3 ).



Fig. 3 Proposed hypothalamic and pituitary genes associated with changes in $\mathrm{LH}$ secretion and growth during pubertal development and adipose tissue genes and secreted proteins related to maturation of the neuroendocrine axis and puberty in the gilt. 1) Hypothalamic $\mathrm{CnRH}$ mRNA expression increased at 3.5 months of age and declined by 6 months of age. 2) Increased excitatory and reduced inhibitory input on $\mathrm{GnRH}$ neurons. 3) Concomitant age related reduction in oestrogen negative feed back on $\mathrm{LH}$ secretion and decreased oestrogen receptor- $\alpha(E R \alpha)$ and increased repressor of oestrogen receptor activity gene (REA) expression at 210 days of age. 4) Development of the endogenous opioid peptide (EOP)-progesterone dependent LH inhibitory pathway. Pathway components: increased proopiomelanocortin (POMC); progesterone receptor (PR) membrane compliment-1; steroid membrane binding protein (SMBP) gene expression at 210 days of age. 5) Expression of the long form leptin receptor (OB-rb) in the leptin responsive sites increased at 3.5 months of age. 6) Pituitary transcription factors, steroidogenic factor 1 (SF1) and Lhx3, and LHß and FSHß gene expression increased with age. 7) Age and adiposity related increase in leptin and insulin like growth factor - ( (ICF-l) gene expression. ( $\uparrow$, increases; $\downarrow$, decreases; ?, unknown/ unclear). 
The authors would like to acknowledge Dr. Yu-Hua Li, Microarray Core Facility, Emory University, Atlanta, GA for microarray analysis.

\section{References}

Ahima RS and Flier IS (2000) Adipose Tissue as an Endocrine Organ. Trends in Endocrinology

and Metabolism $11327-332$

Barb CR, Barrett JB and Kraeling RR (2004) Role of leptin in modulating the hypothalamic-pituitary axis in the pig. Domestic Animal Endocrinology 26 201214

Barb CR, Barrett JB, Rampacek GB and Kraeling RR (1998a) Effects of metabolic fuel restriction on patterns of $\mathrm{LH}$ and $\mathrm{GH}$ secretion and serum leptin concentrations in the prepuberal gilt. Journal of Animal Science 76

Barb CR, Chang W.C, Leshin LS, Rampacek GB and Kraeling RR (1994) Opioid modulation of gonadotropin releasing hormone release from the hypothalamic preoptic area in the pig. Domestic Animal Endocrinology $11375-382$

Barb CR, Hausman GJ and Houseknecht KL (2001) Biology of leptin in the pig. Domestic Animal Endocrinology 21 297-317

Barb CR and Kraeling RR (2004) Role of leptin in the regulation of gonadotropin secretion in farm animals. Animal Reproduction Science 82-83 155-167

Barb CR, Kraeling RR and Rampacek GB (2002) Metabolic regulation of the neuroendocrine axis in pigs. Reproduction Supplement 59 203-217

Barb CR, Kraeling RR, Rampacek GB and Dove CR (1997) Metabolic changes during the transition from the fed to the acute feed-deprived state in prepuberal and mature gilts. Journal of Animal Science 75 781-789

Barb CR, Kraeling RR, Rampacek GB and Estienne MJ (2000) Current concepts of the onset of puberty in the gilt. Reproduction in Domestic Animals Suppl. 6 82-89

Barb CR, Kraeling RR, Rampacek CB and Whisnant CS (1985) Opioid inhibition stimulates luteinizing hormone and prolactin secretion in the gilt. Domestic Animal Endocrinology 2 (2) 93-98

Barb CR, Kraeling RR, Rampacek GB and Whisnant CS (1986) Influence of stage of the estrous cycle on endogenous opioid modulation of luteinizing hormone, prolactin, and cortisol secretion in the gilt. Biology of Reproduction 35 1162-1167

Barb CR, Rampacek GB, Kraeling RR, Estienne MJ, Taras E, Estienne CE and Whisnant CS (1988) Absence of brain opioid peptide modulation of luteinizing hormone secretion in the prepubertal gilt. Biology of Reproduction 39 603-609

Barb CR, Yan X, Azain MJ, Kraeling RR, Rampacek GB and Ramsay TG (1998b) Recombinant porcine leptin reduces feed intake and stimulates growth hormone secretion in swine. Domestic Animal Endocrinology $1577-86$

Brann DW and Mahesh VB (1997) Excitatory amino acids: evidence for a role in the control of reproduction and anterior pituitary hormone secretion. Endocrine Reviews 18 678-700

Cameron JL, Koerker DJ and Steiner RA (1985) Metabolic changes during maturation of male monkeys: possible sign for onset of puberty. American Journal of Physiology 249 E385-E391

Camous S, Prunier A and Pelletier J (1985) Plasma prolactin, LH, FSH, and estrogen excretion patterns in gilts during sexual development. Journal of Animal Science 60 1308-1317

Chen WP, Witkin JW and Silverman AJ (1989) Betaendorphin and gonadotropin releasing hormone synaptic input to gonadotropin releasing hormone neurosecretory cells in the male rat. Journal of Comparative Neurology 286 85-95

Clapper JA, Green ML and Diekman MA (1993a) Serum concentrations of immunoactive and bioactive luteinizing hormone $(\mathrm{LH})$ in gilts. I. Biopotency of $\mathrm{LH}$ increases during prepubertal development. Biology of Reproduction $\mathbf{4 9} \mathbf{7 5 0 - 7 5 6}$

Clapper JA, Green ML and Diekman MA (1993b) Serum concentrations of immunoactive and bioactive luteinizing hormone $(\mathrm{LH})$ in gilts. II. Biopotency of $\mathrm{LH}$ increases at puberty but remains constant throughout the estrous cycle. Biology of Reproduction 49 757-763

Day ML, Imakawa K, Garcia-Winder M, Zalesky DD, Schanbacher BD, Kittok RJ and Kinder JE (1984) Endocrine mechanisms of puberty in heifers: estradiol negative feedback regulation of luteinizing hormone secretion. Biology of Reproduction 31 332-341

Diekman MA and Anderson LL (1982) Quantification of receptors for estradiol-17 beta and progesterone in the pituitary and hypothalamus of prepubertal gilts induced to ovulate with pregnant mare's serum and human chorionic gonadotropin. Biology of Reproduction 27 816-826

Diekman MA and Anderson L.L (1983) Quantification of receptors for estradiol-17 beta and progesterone in the pifuitary and hypothalamus of gilts during the estrous cycle and early pregnancy. Biology of Reproduction 29 946-952

Diekman MA, Trout WE and Anderson LL. (1983) Serum profiles of LH, FSH AND prolactin from 10 weeks of age until puberty in gilts. Journal of Animal Science $56 \quad 139-145$

Dierschke, D. J., Karsch, F. J., Weick, R. F., Weiss, G., Hotchkiss J. \& Knobil, E. (1974) Hypothalamic-pituitary regulation of puberty in the Rhesus monkey. In: Control of the Onset of Puberty leds M. M. Grumbach, D. G. Grave \& F. E. Mayer), Wiley and Sons, Wiley and Sons.

Dorling AA, Todman MC, Korach KS and Herbison AE 
(2003) Critical role for estrogen receptor alpha in negative feedback regulation of gonadotropin-releasing hormone mRNA expression in the female mouse. Neuroendocrinology 78 204-209

Drisko JE, Faidley TD, Chang CH, Zhang D, Nicolich S, Hora DF, McNamara L, Rickes E, Abribat T, Smith RG and Hickey GJ (1998) Hypophyseal-portal concentrations of growth hormone-releasing factor and somatostatin in conscious pigs: relationship to production of spontaneous growth hormone pulses. Proceedings of the Society for Experimental Biology and Medicine 217 188-196

Dubreuil P, Pelletier C, Petitclerc D, Lapierre H, Couture Y, Brazeau P, Gaudreau P and Morisset (1987) Influence of age and sex on basal secretion of growth hormone $(\mathrm{GH})$ and on $\mathrm{CH}$-induced release by porcine $\mathrm{GH}$-releasing factor pGRF(1-29NH2) in growing pigs. Domestic Animal Endocrinology 4 299307

Esbenshade KL, Paterson AM, Cantley TC and Day BN (1982) Changes in plasma hormone concentrations associated with the onset of puberty in the gilt. Journal of Animal Science 54 320-324

Estienne MJ, Harter-Dennis JM, Barb CR and Hartsock TG (1995) Luteinizing hormone and growth hormone concentrations in serum of prepubertal gilts treated with $\mathrm{N}$-methyl-D,L-aspartate. Domestic Animal Endocrinology 12 207-213

Frisch RE (1984) Body fat, puberty and fertility. Biological Reviews 59 161-188

Gay VL and Plant TM (1988) Sustained intermittent release of gonadotropin-releasing hormone in the prepubertal male Rhesus monkey induced by $\mathrm{N}$-methyl-D,L- aspartic acid. Neuroendocrinology 48147 . 152

Gore AC, Wu TI, Rosenberg IJ and Roberts JL. (1996) Gonadotropin-releasing hormone and NMDA receptor gene expression and colocalization change during puberty in female rats. Journal of Neuroscience 16 5281-5289

Herbison AE (1998) Multimodal influence of estrogen upon gonadotropin-releasing hormone neurons. Endocrine Reviews 19 302-330

Hrabovszky E, Steinhauser A, Barabas K, Shughrue PJ, Petersen SL, Merchenthaler I and Liposits Z (2001) Estrogen receptor-beta immunoreactivity in luteinizing hormone-releasing hormone neurons of the rat brain. Endocrinology 142 3261-3264

Kineman RD, Kraeling RR, Crim JW, Leshin LS, Barb CR and Rampacek GB (1989) Localization of proopiomelanocortin (POMC) immunoreactive neurons in the forebrain of the pig. Biology of Reproduction $401119-1126$

Kineman RD, Leshin LS, Crim JW, Rampacek GB and Kraeling RR (1988) Localization of luteinizing hormone-releasing hormone in the forebrain of the pig. Biology of Reproduction 39 665-672

Kraeling RR and Barb CR (1990) Hypothalamic control of gonadotrophin and prolactin secretion in pigs. Journal of Reproduction and Fertility Supplement 40 3-17
Kraeling RR, Barb CR, Leshin LS and Rampacek GB (1992) Central nervous system peptide and amino acid modulation of luteinizing hormone and prolactin secretion in the pig. Journal of Physiology and Pharmacology 43 (4) 79-103

Lawrence CB, Turnbull AV and Rothwell NJ (1999) Hypothalamic control of feeding. Current Opinion in Neurobiology 9 778-783

Lee CY, Bazer FW, Etherton TD and Simmen FA (1991) Ontogeny of insulin-like growth factors (IGF-I and IGF-II) and IGF-binding proteins in porcine serum during foetal and postnatal development. Endocrinology 128 2336-2344

Leshin LS, Barb CR, Kiser TE, Rampacek GB and Kraeling RR (1994) Growth hormone-releasing hormone and somatostatin neurons within the porcine and bovine hypothalamus. Neuroendocrinology 59 251-264

Lin J, Barb CR, Kraeling RR and Rampacek GB (2001) Developmental changes in the long form leptin receptor and related neuropeptide gene expression in the pig brain. Biology of Reproduction 641614 1618

Lin J, Barb CR, Matteri RL, Kraeling RR, Chen X, Meinersmann RJ and Rampacek GB (2000) Long form leptin receptor mRNA expression in the brain, pituitary, and other tissues in the pig. Domestic Animal Endocrinology 19 53-61

Loftus TM (1999) An adipocyte-central nervous system regulatory loop in the control of adipose homeostasis. Cell Developmental Biology 10 11-18

Lułz JB, Rampacek GB and Kraeling RR (1985) Induction of ovulation in the prepuberal gilt by pulsatile administration of gonadotropin releasing hormone. Domestic Animal Endocrinology 2 (1) 61-65

Lutz JB, Rampacek GB, Kraeling RR and Pinkert CA (1984) Serum luteinizing hormone and estrogen profiles before puberty in the gilt. Journal of Animal Science 58 (3) 686-691

Ma YJ, Costa ME and Ojeda SR (1994) Developmental expression of the gene encoding transforming growth factor alpha and its receptor in the hypothalamus of the female rhesus macaques. Neuroendocrinology $60346-359$

Mabry IW, Weaver WM, Benyshek LL and Marks MA (1985) Phenotypic and genetic parameters for growth, puberty and composition traits in gilts. Growth 49 282.289

Matteri RL (2001) Overview of central targets for appetite regulation. Journal of Animal Science 79 E148E158

Montano MM, Ekena K, Delage-Mourroux R, Chang W, Martini P and Katzenellenbogen BS (1999) An estrogen receptor-selective coregulator that potentiates the effectiveness of antiestrogens and represses the activity of estrogens. Proceedings of the National Academy of Sciences U S A 96 6947-6952

Netchine 1, Sobrier ML, Krude H, Schnabel D, Maghnie M, Marcos E, Duriez B, Cacheux V, Moers A, Goossens M, Gruters A and Amselem S (2000) Mutations in L.HX3 result in a new syndrome revealed by combined pituitary hormone deficiency. Nature Genetics 2 182-186 
Ojeda, S. R. \& Terasawa, E. (2002) Neuroendocrine regulation of puberty. In: Hormones, Brain and Behavior leds D. W. Pfaff, A. P. Arnold, A. M. Etgen, S. E. Fahrbach \& R. T. Rubin), pp. 589-659. Academic Press, New York, Academic Press, New York.

Ojeda, S. R. \& Urbanski, H. F. (1994) Puberty in the rat. In: The physiology of reproduction (eds E. Knobil \& 1. Neill), pp. 363-409. Raven Press, New York.

Pelletier J, Carrez-Camous S and Thiery IC (1981) Basic neuroendocrine events before puberty in cattle, sheep and pigs. Journal of Reproduction and Fertility Supplement 30 91-102

Plant TM and Barker-Gibb ML (2004) Neurobiological mechanisms of puberty in higher primates. Human Reproduction Update 10 67-77

Prunier A, Chopineau M, Mounier AM and Mormède P (1993) Patterns of plasma LH, FSH, oestradiol and corticosteroids from birth to the first oestrous cycle in Meishan gilts. Journal of Reproduction and Fertility 98 313-319

Qian H, Barb CR, Compton MM, Hausman GJ, Azain MJ, Kraeling RR and Baile CA (1999) Leptin mRNA expression and serum leptin concentrations as influenced by age, weight and estradiol in pigs. Domestic Animal Endocrinology 16 135-143

Ramirez DV and McCann SM (1963) Comparison of the regulation of luteinizing hormone (LH) secretion in immature and adult rats. Endocrinology 72452

Robison OW (1976) Growth patterns in swine. Journal of Animal Science 42 1024-1035

Sanchez-Criado JE, Martin De Las MJ, Bellido C, TenaSempere M, Aguilar R and Blanco A (2004) Biological role of pituitary estrogen receptors ERalpha and ERbeta on progesterone receptor expression and action and on gonadotropin and prolactin secretion in the rat. Neuroendocrinology 79 247-258

Savage IJ, Yaden BC, Kiratipranon P and Rhodes SJ (2003) Transcriptional control during mammalian anterior pituitary development. Gene 319 1-19
Sesti LAC and Britt JH (1992) Elicitation of release of luteinizing hormone by n-methyl-d,l-aspartic acid during three paradigms of suppressed secretion of luteinizing hormone in the female pig. Domestic Animal Endocrinology 9 (2) 105-114

Sisk CL and Foster DL (2004) The neural basis of puberty and adolescence. Nature Neuroscience 7 1040-1047

Smith TP, Showalter AD, Sloop KW, Rohrer GA, Fahrenkrug SC, Meier BC and Rhodes SJ (2001) Identification of porcine $\mathrm{Lh} \times 3$ and SF 1 as candidate genes for QTL affecting growth and reproduction traits in swine. Animal Genetics 32 344-350

Spencer GS, Macdonald AA, Buttle HL, Moore LG and Carlyle SS (1991) Intracerebral administration of insulin-like growth factor I decreases circulating growth hormone levels in the foetal pig. Acta Endocrinologica (Copenhagen) 124 563-568

Terasawa E and Fernandez DL (2001) Neurobiological mechanisms of the onset of puberty in primates. Endocrine Reviews 22 111-151

Thind KK and Goldsmith PC (1988) Infundibular gonadotropin-releasing hormone neurons are inhibited by direct opioid and autoregulatory synapses in juvenile monkeys. Neuroendocrinology 47 203-216

Tummaruk P, Lundeheim N, Einarsson $S$ and Dalin AM (2000) Factors influencing age at first mating in purebred Swedish Landrace and Swedish Yorkshire gilts. Animal Reproduction Science 63 241-253

Vician L, Adams LA, Clifton DK and Steiner RA (1991) Pubertal changes in pro-opiomelanocortin and gonadotropin-releasing hormone gene expression in the brain of the male monkey. Molecular and Cellular Neurosciences 2 31-38

Whitley NC, Barb CR, Utley RV, Popwell JM, Kraeling RR and Rampacek GB (1995) Influence of stage of the estrous cycle on insulin-like growth factor-l modulation of Juteinizing hormone secretion in the gilt. Biology of Reproduction 53 1359-1364 